\title{
FORGÁCSOLÁSI PARAMÉTERKOMBINÁCIÓK JÓSÁGI TÉNYEZŐJÉNEK FUZZY MODELL ALAPÚ BECSLÉSE
}

\section{FUZZY-BASED QUALITY FACTOR PREDICTION FOR DIFFERENT CUTTING PARAMETER COMBINATIONS}

\author{
Tóthné Laufer Edit
}

Óbudai Egyetem, Bánki Donát Gépész és Biztonságtechnikai Mérnöki Kar, Mechatronikai és Jármütechnikai Intézet, 1081 Magyarország, Budapest, Népszínház u. 8; laufer.edit@bgk.uni-obuda.hu

\begin{abstract}
In this paper a novel fuzzy-based approach is introduced to define a quality factor of the cutting parameters (cutting speed, feed, and depth of cut) for hypereutectic aluminum alloys with a diamond tool. This evaluation structure allows one to taking into account the burred boundaries between the grades of the input parameters, and the expert knowledge can be built into the system by the rule base definition, and it applies fuzzy logic-based decision model.
\end{abstract}

Keywords: surface roughness, fine turning, aluminum alloy, fuzzy inference.

\section{Összefoglalás}

Ebben a cikkben egy fuzzy modell alapú módszert mutatok be, melynek segítségével egy jósági tényező rendelhető a forgácsolási paraméterekhez (forgácsoló sebesség, előtolás, fogásmélység) gyémánt szerszámmal megmunkált hipereutektikus alumíniumötvözet esetén. A fuzzy alapú kiértékelés lehetővé teszi az elmosódott határok figyelembe vételét a bemenő paraméterek tartományainál, valamint a rendelkezésre álló szakértői tudás is beépíthető a rendszerbe a szabálybázis által és fuzzy logikán alapuló döntési modellt alkalmazunk.

Kulcsszavak: felületi érdesség, finomesztergálás, aluminium ötvözet, fuzzy következtetés.

\section{Bevezetés}

A forgácsolt termékek egyik fontos jellemzője a gyártott felületi érdesség, ezért technológiai tervezésnél célszerü becsülni az elérni kívánt értékét. Jellemzői (pl. átlagos felületi érdesség, Ra, $\mu \mathrm{m}$; egyenetlenség magasság, Rz, $\mu \mathrm{m}$ ) nagyban függnek a forgácsoló paraméterektől, ezért a köztük fennálló kapcsolat vizsgálata napjainkban is fontos kutatási terület, számos kutató foglakozik a témával [1]-[5].

Ilyen típusú feladatoknál a bemenő paraméterek együttes hatásának vizsgálata okozhat problémát, hiszen az eredmény jóságának meghatározásakor a forgácsolt felület érdességét és a termelékenységet egyaránt figyelembe kell venni. Abban az esetben, ha az érdességi paraméterek jók, de hosszú időt vesz igénybe a munkadarab előállítása, akkor a beállítások nem megfelelőek. A kidolgozott modell célja, megtalálni az egyensúlyt. A komplex feladatok [6], nemlineáris rendszerek [8], valamint a cikk témájához kapcsolódóan forgácsolóerő meghatározásakor [9],[10] is népszerü fuzzy megközelítés alkalmazható ilyen esetben is, mivel a fuzzy alapú rendszerek 
képesek kezelni, hogy sem a bemenő paraméterek, sem a felületi érdesség és a termelékenység nem adható meg éles határokkal, ezek értéke fokozatosan változik a forgácsolási paraméterektöl függően. Az ilyen rendszerek elmosódott határokkal, fuzzifikált paraméterekkel dolgoznak, a szakértői tudás beépíthető a rendszerbe a szabálybázis által, és a döntési modellben fuzzy alapú közelítő következtetést alkalmaznak [14],[15].

A cél olyan fuzzy modell kidolgozása volt, mellyel a fenti problémák kezelhetök, egy a különböző forgácsolási paraméterek rangsorolhatóságát szolgáló jósági tényező meghatározása által. Így kiválaszthatók az optimális forgácsolási paraméterek.

\section{A paraméterek kiválasztása}

Munkám során a gyártott felületi érdességre ható tényezők közül az esztergálásnál a beállítható forgácsolási paramétereket, relatív mozgásviszonyok - vizsgáltam, ezek a forgácsoló sebesség ( $v c, \mathrm{~m} / \mathrm{min}$ ), az előtolás $(f, \mathrm{~mm})$, és a fogásmélység $(a, \mathrm{~mm})$.

$\mathrm{Az}$ alumínium alkatrészek esztergálása szinte mindig befejező technológia. A cél ilyen esetben, hogy az $\mathrm{Ra}, \mathrm{Rz}$ értékeket minimalizálni kell (1) a termelékenység maximalizálása mellett (2).

$$
\begin{gathered}
R a \Rightarrow \text { Min } \quad \mid R z \Rightarrow \text { Min } \\
P f=v_{c} \cdot f \Rightarrow \text { Max }
\end{gathered}
$$

A fuzzy modell alapjául a Horváth et al. által definiált kívánatossági függvények szolgáltak [3]. A modell megalkotása során szilícium ötvözésű hipereutektikus alumíniumötvözet gyémánt szerszámmal történő finomesztergálását vizsgáltam. Keménység: $117 \mathrm{HB}_{2,5 / 62,5 / 30}$. Szerszám kód: DCGW $11 T 304$ hagyományos (ún. ISO) élgeometriával, az élanyag MDC (monokristályos gyémánt).

\section{A fuzzy modell felépítése}

A fuzzy modell feladata a bemeneti tényezőkhöz ( $\left.v_{c}, f, a\right)$ egy jósági tényező hozzárendelése, melynek (1), (2) együttes figyelembe vételével való rangsorolásával megkapható az optimális paraméter kombináció. A kiértékelés Mamdani-típusú következtetési rendszeren alapul, melyben a bemenő paraméterek $x_{1}, x_{2}, \ldots, x_{n}$, a kimenő paraméter $y$, a rendszer a következő szerkezetü szabályokkal írható le [17]:

IF $\mathrm{x}_{1}$ is $A_{l, i_{1}}$ and $\ldots$ and $\mathrm{x}_{\mathrm{n}}$ is $A_{n, i_{n}}$ THEN y is $Y_{i_{1}, \ldots, i_{n}}$

ahol $A_{k, i_{k}}$ a $k$-adik bemenethez tartozó $i_{k}$-dik szabály-antecedens, $Y_{i_{1}, \ldots, i_{n}}$ jelöli a szabályok következmény részét, $i_{j}=1 . . n_{j}$, és $n_{j}$ a j-dik bemenethez tartozó antecedensek száma. A szabály-premisszák a bemenetek összes lehetséges kombinációjából állíthatók elő.

A kiértékelés első lépése a fuzzifikálás, amikor egy tagsági értéket (MF) rendelünk az aktuális bemenethez egy trapéz alakú tagsági függvény segítségével, melyek a 1-3. ábrán láthatók.

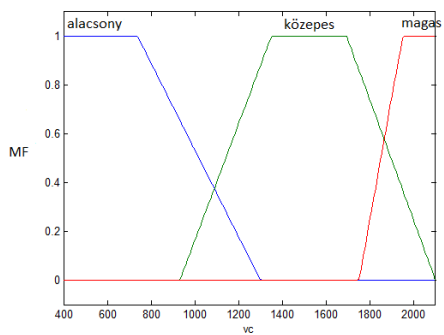

1. ábra. Forgácsoló sebesség tagsági függvényei

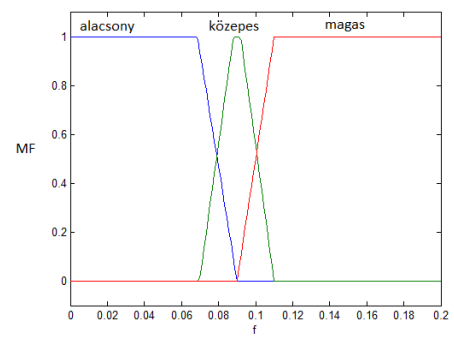

2. ábra. Elötolás tagsági függvényei 


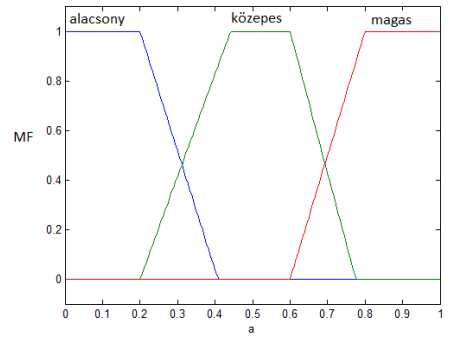

3. ábra. Fogásmélység tagsági függvényei

Az egyes bemenetekhez tartozó tagsági értékek összekacsolására a szorzat operátort alkalmaztam (4), az adott szabálypremissza tüzelési szintjének meghatározására [19].

$$
\mathrm{w}_{\mathrm{i}}=\mu_{\mathrm{A}_{\mathrm{ki}_{\mathrm{k}}}}\left(\mathrm{v}_{\mathrm{c}}\right) \mu_{\mathrm{B}_{\mathrm{kj}_{\mathrm{k}}}}(\mathrm{f}) \mu_{\mathrm{C}_{\mathrm{kl}_{\mathrm{k}}}}(\mathrm{a})
$$

ahol $\mu_{\mathrm{A}_{\mathrm{ki}_{\mathrm{k}}}}\left(\mathrm{v}_{\mathrm{c}}\right), \mu_{\mathrm{B}_{\mathrm{kj}_{\mathrm{k}}}}(\mathrm{f}), \mu_{\mathrm{C}_{\mathrm{kl}}}(\mathrm{a})$ rendre a $\mathrm{v}_{\mathrm{c}}, \mathrm{f}, \mathrm{a}$, bemenetekhez tartozó tagsági értékek. Ezután az implikáció szintén szorzat operátor segítségével történik (5).

$$
y_{Y_{i}}=w_{i} \mu_{Y i}
$$

ahol $w_{i}$ az $i$-dik szabályhoz tartozó tüzelési szint, $\mu_{Y i}$ az $i$-dik szabályhoz tartozó következtetés. A kimeneti tagsági függvény a 4. ábrán látható.

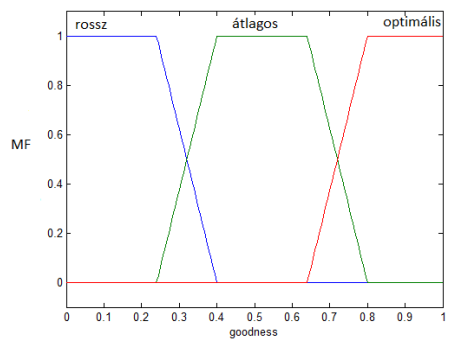

4. ábra. Jósági tényezö tagsági függvényei

A teljes rendszerkimenet meghatározása érdekében a szabályonként kapott következtetéseket a tüzelési szintek súlyozott átlagaként aggregáltam (6).

$$
y=\frac{\sum_{i=1}^{n} w_{i} y_{Y_{i}}}{\sum_{i=1}^{n} w_{i}}
$$

ahol $w_{i}$ az $i$-edik szabályhoz tartozó tüzelési szint, $y_{Y_{i}}$ az $i$-edik szabálykimenet, $n$ pedig a szabályok száma.

Végül a kapott fuzzy halmaz reprezentáló crisp érték előállítására a COG defuzzifikációs módszert alkalmaztam, mely a görbe alatti terület súlyközéppontját határozza meg (7) segítségével.

$$
y_{\text {out }}=\frac{\int_{y \in \mu_{Y}} \mu_{Y}(y) y d y}{\int_{y \in \mu_{Y}} \mu_{Y}(y) d y}
$$

ahol $\mu_{\mathrm{Y}}$ a szabálykövetkezmény.

\section{A módszerek összehasonlítása}

A numerikus és a fuzzy modellt egyaránt Matlab környezetben valósítottam meg, a bemenő adatok $\left(v_{c}, f, a\right)$ kiválasztása a vizsgált paraméterek jellemzői, a tényleges beállítható értékek figyelembe vételével történt (1. táblázat). A kiértékelést elvégeztem mindkét modell segítségével és a kapott rangsort hasonlítottam össze. A módszerek különbözősége miatt az eredmények számszerüen nem egyeznek meg, de a cél nem is ez, hanem a kombinációk rangsorolása volt az optimum kiválasztása érdekében.

1. táblázat. A bemenö paraméterek jellemzői

\begin{tabular}{|c|c|c|}
\hline $\begin{array}{c}\text { Név, jel, mértékegy- } \\
\text { ség }\end{array}$ & $\begin{array}{c}\text { Értelmezési } \\
\text { tartomány }\end{array}$ & Inkrement \\
\hline $\begin{array}{c}\text { Forgácsoló sebesség, } \\
v_{c}, \mathrm{~m} / \mathrm{min}\end{array}$ & {$[500,2000]$} & 50 \\
\hline Előtolás, $f, \mathrm{~mm}$ & {$[0.05,0.12]$} & 0.01 \\
\hline $\begin{array}{c}\text { Fogásmélység, } a, \\
\mathrm{~mm}\end{array}$ & {$[0.2,0.8]$} & 0.05 \\
\hline
\end{tabular}

Ahogy a 2. táblázatban is látható, a kapott rangsorok megegyeznek, ezzel a fuzzy 
modell használhatóságát igazoltam. Utóbbinak nagy előnye a numerikus modellel szemben, hogy a kevésbé kedvező beállítások rangsorolását is lehetővé teszi. Az optimális tartománnyal kapcsolatban megállapítható, hogy átlagos előtolás esetén minél nagyobb a forgácsoló sebesség, és minél kisebb a fogásmélység az eredmény annál közelebb van az optimálishoz.

2. táblázat. A modellek összehasonlitása

\begin{tabular}{|c|c|c|c|c|c|}
\hline & $\begin{array}{c}\mathbf{v}_{\mathbf{c}}, \\
\mathbf{m} / \mathbf{m i n}\end{array}$ & $\mathbf{f , ~} \mathbf{m m}$ & $\mathbf{a , ~} \mathbf{m m}$ & $\mathbf{D}$ & Jóság \\
\hline 1. & 2000 & 0.09 & 0.02 & 0.3861 & 0.7718 \\
\hline 2. & 1950 & 0.09 & 0.02 & 0.3578 & 0.7431 \\
\hline 3. & 2000 & 0.09 & 0.03 & 0.3260 & 0.7058 \\
\hline 4. & 1900 & 0.09 & 0.2 & 0.3219 & 0.6963 \\
\hline 5. & 1950 & 0.09 & 0.25 & 0.3028 & 0.6858 \\
\hline 6. & 1900 & 0.09 & 0.25 & 0.2731 & 0.6525 \\
\hline 7. & 1850 & 0.09 & 0.2 & 0.2723 & 0.6442 \\
\hline 8. & 2000 & 0.09 & 0.3 & 0.2596 & 0.6435 \\
\hline 9. & 1950 & 0.09 & 0.3 & 0.2423 & 0.6309 \\
\hline 10. & 1850 & 0.09 & 0.25 & 0.2316 & 0.6145 \\
\hline
\end{tabular}

\section{Következtetések}

Az optimális forgácsolási paraméter beállítások meghatározása érdekében egy fuzzy logikán alapuló modellt építettem. A kiértékelés célja a különböző paraméter értékekhez (vc, f, a) egy jósági tényező hozzárendelése volt, mellyel a különböző kombinációk rangsorolhatók. Ezáltal az felületi érdesség - termelékenység kombinációhoz tartozó beállítások meghatározhatók. A fuzzy modellt egy hasonló célú ugyanilyen feltételekkel dolgozó numerikus modellel [4] hasonlítottam össze, ezzel igazoltam a fuzzy modell alkalmazhatóságát.

\section{Szakirodalmi hivatkozások}

[1] Aouici, H. et. al: Analysis of surface roughness and cutting force components in hard turning with CBN tool: Prediction model and cutting conditions optimization. Measurement, Vol. 45, 2012, pp. 344-353.

[2] Asiltürk, I.; Akkus, H.: Determining the effect of cutting parameters on surface roughness in hard turning using the Taguchi method. Measurement, Vol. 44, 2011, pp. 1697-1704.

[3] Horváth, R. et. al: Application of RSM method for the examination of diamond tools. Acta Polytechnica Hungarica, Vol. 11, No. 2, 2014, pp. 137-147, DOI: 10.12700/APH. 11.02.2014.02.8

[4] Horváth, R.; Drégelyi-Kiss, Á.: Analysis of surface roughness parameters in aluminium fine turning with diamond tool. Proc. of the Measurement 2013 Conf., Smolenice, Slovakia, 2013, pp. 275-278.

[5] Drégelyi-Kiss, A. et. al: Comparison of capability calculations of surface roughness measurement in automotive industry. Proc. of the ISMQC 2013, Cracow, Poland, 11-13. Sept, 2013, pp. 1-4.

[6] Pokorádi, L.: Fuzzy logika alkalmazása a repülötechnika üzemeltetésében. Repüléstudományi Közlemények XII: (29), pp. 349356. (2000)

[8] Tomescu, M. L. et. al: Stability analysis method for fuzzy control systems dedicated controlling nonlinear processes. Acta Polytechnica Hungarica, Vol. 4, No. 3, pp. 127-141, 2007.

[9] Aguero, E. et. al: Fuzzy model of cutting process on a milling machine. Intelligent Systems Engineering, Vol. 3, No. 4, pp. 236244, 1994.

[10] Kim, D.; Jeon, D.: Fuzzy-logic control of cutting forces in CNC milling processes using motor currents as indirect force sensors. Precision Engineering, Vol. 35, No. 1, pp. 143-152, 2011.

[14] Zhang X. et. al: Method for multiple attribute decisionmaking under risk with interval numbers. Int. J. of Fuzzy Systems, Vol. 12, No. 3, pp. 237-242, Sept. 2010.

[15] Takács, M.: Approximate Reasoning in Fuzzy Systems Based on Pseudo-analysis and Uninorm Residuum. Acta Polytechnica Hungarica, Vol. 1, No. 2, pp. 49-62, 2004

[17] Türkşen, I. B. et. al: Comparision of fuzzy functions with fuzzy rule base approaches. Int. Journal of Fuzzy Systems, Vol. 8, No. 2, pp. 137-149, Sept. 2006

[21] Merigó J. et. al.: Fuzzy generalized hybrid aggregation operators and its application in fuzzy decision making. Int. J. of Fuzzy Systems, Vol. 12, No. 1, pp. 15-24, 2010. 